\title{
A SHARPENED VERSION OF THE FUNDAMENTAL TRIANGLE INEQUALITY
}

\author{
SHANHE WU
}

Abstract. In this note, we show a sharpened version of the classical fundamental triangle inequality, as follows

$2 R^{2}+10 R r-r^{2}-2(R-2 r) \sqrt{R^{2}-2 R r} \cos \phi \leqslant s^{2} \leqslant 2 R^{2}+10 R r-r^{2}+2(R-2 r) \sqrt{R^{2}-2 R r} \cos \phi$, where $\phi=\min _{1 \leqslant i<j \leqslant 3}\left|A_{i}-A_{j}\right|$.

Mathematics subject classification (2000): 26D05, 26D15, 51N35.

Key words and phrases: Triangle, fundamental triangle inequality, Euler's inequality, sharpen.

\section{REFERENCES}

[1] É. Rouché And Ramus, Question 233, Nouv. Ann. Math., 10(1851), 353-355.

[2] D. S. Mitrinović, J. E. PEČ ARIĆ AND V. VOLENEC, Recent Advances in Geometric Inequalities. Kluwer Academic Publishers, Dordrecht, Netherlands, 1989.

[3] O. Bottema, R. Z. Djordjević, R. R. JAnić, D. S. Mitrinović And P. M. VASić, Geometric Inequalities. Wolters-Noordhoff, Groningen, 1969.

[4] D. S. Mitrinović, J. E. Peč ARić, V. Volenec And J. Chen, Addenda to the Monograph: Recent Advances in Geometric Inequalities(I). Journal of Ningbo University, 4(2)(1991)80-92.

[5] Z. SHAN, Geometric Inequality in China. Jiangsu Education Publishing House, Nanjing, 1996 (in Chinese).

[6] J. C. KUANG, Applied Inequalities, 2nd ed., Shandong Science and Technology Press, Jinan, 1993 (in Chinese).

[7] R. A. Satnoianu, General power inequalities between the sides and the circumscribed and inscribed radii related to the fundamental triangle inequality. Math. Inequal. Appl., 5(4)(2002), 745-751.

[8] R. A. SATNOIANU, Refined geometric inequalities between two or more triangles obtained by dedublation. Math. Inequal. Appl., 7(2)(2004), 289-298.

[9] S. WU, Generalization and sharpness of Finsler-Hadwiger's inequality and its applications. Math. Inequal. Appl., 9 (3) (2006), 421-426.

[10] SH-H. WU AND ZH-H. ZHANG, A class of inequalities related to the angle bisectors and the sides of a triangle. J. Inequal. Pure Appl. Math., 7 (3) (2006), Article 108. 